\title{
Detection of Salmonella spp, Salmonella Enteritidis and Typhimurium in naturally infected broiler chickens by a multiplex PCR-based assay
}

\author{
F.G. Paião ${ }^{1}$, L.G.A. Arisitides ${ }^{1}$, L.S. Murate $^{1}$, G.T. Vilas-Bôas ${ }^{2}$, \\ L.A. Vilas-Boas ${ }^{2}$, M. Shimokomaki ${ }^{1}$ \\ ${ }^{1}$ Universidade Estadual de Londrina, Centro de Ciências Agrárias, \\ Departamento de Ciência e Tecnologia de Alimentos, Londrina, PR, Brazil. \\ ${ }^{2}$ Universidade Estadual de Londrina, Centro de Ciências Biológicas, \\ Departamento de Biologia Geral, Londrina, PR, Brazil.
}

Submitted: December 16, 2010; Approved: September 13, 2012.

\begin{abstract}
The presence of Salmonella in the intestinal tract, on the chickens skin and among their feathers, may cause carcasses contamination during slaughtering and processing and possibly it is responsible by the introduction of this microorganism in the slaughterhouses. A rapid method to identify and monitor Salmonella and their sorovars in farm is becoming necessary. A pre-enriched multiplex polymerase chain reaction (m-PCR) assay employing specific primers was developed and used to detect Salmonella at the genus level and to identify the Salmonella enterica serovar Enteritidis ( $S$. Enteritidis) and Salmonella enterica serovar Typhimurium (S. Typhimurium) in broiler chicken swab samples. The method was validated by testing DNA extract from 90 fresh culture cloacal swab samples from poultry chicken cultured in phosphate buffer peptone water at $37^{\circ} \mathrm{C}$ for $18 \mathrm{~h}$. The final results showed the presence of Salmonella spp. in $25 \%$ of samples, S. Enteritidis was present in $12 \%$ of the Salmonella-positive samples and S. Typhimurium in 3\% of the samples. The m-PCR assay developed in this study is a specific and rapid alternative method for the identification of Salmonella spp. and allowed the observation of specific serovar contamination in the field conditions within the locations where these chickens are typically raised.
\end{abstract}

Key words: aviculture, bacteria, detection.

\section{Introduction}

Salmonella enterica is the representative pathogen causing salmonellosis in humans and animals worldwide and is sub-classified into more than 2500 serovars. Salmonella serovars Enteritidis and Typhimurium are the most important agents of food-borne salmonellosis in humans (Popoff et al., 2003). S. Enteritidis was the most prevalent serovar isolated from patients and food preparations in a survey conducted in southern Brazil from 1999 to 2008 (Kottwitz et al., 2010). It was estimated that approximately $75 \%$ of human Salmonella infection cases were due to contaminated food products derived from beef, pork, poultry and eggs (Hald et al., 2004) Poultry often become infected through the consumption of contaminated feed, cross-con- tamination in brooding houses, or during slaughter and processing (Doyle et al., 2006; Fratamico, 2003). With increasing regulatory pressure placed on poultry and livestock processors to reduce pathogen contamination in processed meats, more emphasis is likely to be focused on reducing pathogen contamination on farms (Rasschaert et al., 2008). Therefore, development of a rapid and sensitive method to Salmonella spp and their serovars is desirable. Several techniques for improving the detection of Salmonella serovars in fecal material such as the use of a selective culture medium and enzyme-linked immunosorbent assay have been developed (Araj and Chugh, 1987, Aspinall et al., 1992). However, problems remain with sensitivity and specificity that have limited routine use of these procedures. In general, these methods are laborious and

Send correspondence to M. Shimokomaki. Universidade Tecnológica Federal do Paraná, Campus Londrina, Avenida dos Pioneiros 3131, 86036-370 Londrina, PR, Brazil. E-mail: mshimo@uel.br. 
time-consuming, in contrast with molecular methods that reduce the time of diagnostic with the same efficiency (Aabo et al., 1993, Malorny et al., 2009). We herein report a simple, accurate and fast PCR assay to detect and identify Salmonella at the genus level and the serovars Enteritidis and Typhimurium, that utilizes the sequences of the Inv-A, IE-1 and Flic-C respectively (Fratamico and Strobaugh 1998, Rahn et al., 1992; Wang and Yeh, 2002) as targets for amplification of Salmonella bacteria in broiler swabs.

\section{Materials and Methods}

\section{Bacterial strains}

$S$. Enteriditis (ATCC 13076) and Typhimurium (ATCC 14028) were used as reference strains in the m-PCR assays. The Salmonella strains and the non-Salmonella bacterial strains used in this study are listed in Table 1. The isolates were grown in brain and heart infusion broth (Himedia) at $37^{\circ} \mathrm{C}$ for $24 \mathrm{~h}$.

\section{DNA extraction}

Pure culture from the different bacteria genera and swabs collected from broiler chickens were cultured in $10 \mathrm{~mL}$ of phosphate buffer peptone water (Acumedia) for $18 \mathrm{~h}$. One milliliter of these cultures was then centrifuged at $14,000 \times g$ and re-suspended in $1 \mathrm{~mL} 0.9 \%(\mathrm{~m} / \mathrm{v})$ saline solution by vortexing. The tubes were centrifuged at $14,000 \times$ $g$ for $5 \mathrm{~min}$, and the supernatants were carefully discarded. The pellets were re-suspended in $0.5 \mathrm{~mL} 0.1 \%$ Triton X100 (Nuclear) by vortexing. The cell suspensions were held in a boiling water-bath for $10 \mathrm{~min}$ to lyse the cells and immediately placed on ice bath. The tubes were then centrifuged for $5 \mathrm{~min}$ at $14,000 \times g$. The supernatants were carefully transferred into new microcentrifuge tubes, and a $4 \mu \mathrm{L}$ aliquot of the supernatant was used as the template DNA for the m-PCR.

\section{m-PCR experiments}

Reactions were carried out in a total volume of $20 \mu \mathrm{L}$ containing $1 \mathrm{U}$ Taq Polymerase (Invitrogen), $1 \times$ Taq buffer (5 mM KCl, 10 mM Tris-HCl, pH 8.5), $1.5 \mathrm{mM} \mathrm{MgCl}_{2}$, $0.1 \mathrm{mM}$ dNTPs (Promega), $0.9 \mu \mathrm{M}$ Inv-A primers, and $0.4 \mu \mathrm{M}$ IE1 and Flic-C primers (Invitrogen). Amplifications were performed in a DNA thermocycler (MJ Research, PTC 100) The m-PCR protocol consisted of an initial denaturation step for $5 \mathrm{~min}$ at $95{ }^{\circ} \mathrm{C}$ followed by 30 cycles of $1 \mathrm{~min}$ at $95{ }^{\circ} \mathrm{C}, 1 \mathrm{~min}$ at $58^{\circ} \mathrm{C}$, and $30 \mathrm{~s}$ at $72{ }^{\circ} \mathrm{C}$ ) and by a final extension step for $7 \mathrm{~min}$ at $72{ }^{\circ} \mathrm{C}$. The PCR products were analyzed by electrophoresis using $1.5 \%$ agarose gels (Rozen et al., 2000) with TBE (45 mmol L $\mathrm{m}^{-1}$ Tris, $\mathrm{pH} 8.3,45 \mathrm{mmol} \mathrm{L}^{-1}$ borate, and $2 \mathrm{mmol} \mathrm{L}^{-1}$ EDTA) as the running buffer. The gels were stained with $\mathrm{SYBR}^{\circledR}$ Safe

Table 1 - Bacterial strains used to assay the specificity of the Multiplex PCR. Salmonella and related bacteria were grown in phosphate-buffered peptone water for $24 \mathrm{~h}$ at $37^{\circ} \mathrm{C}$ prior DNA extraction to use in this m-PCR assay.

\begin{tabular}{lcccc}
\hline Strains & Number of strains & \multicolumn{3}{c}{ m-PCR positive results from amplified products } \\
\cline { 2 - 5 } & & $796 \mathrm{bp}$ & $316 \mathrm{bp}$ & $432 \mathrm{bp}$ \\
\hline S. Enteritidis & 5 & 5 & 5 & 0 \\
S. Typhimurium & 3 & 3 & 0 & 3 \\
S. Agnona & 2 & 2 & 0 & 0 \\
S. Dublin & 2 & 2 & 0 & 0 \\
S. Infantis & 4 & 4 & 0 & 0 \\
S. Montevideo & 2 & 2 & 0 & 0 \\
S. Newport & 2 & 2 & 0 & \\
Bacillus cereus & 1 & 0 & 0 & 0 \\
Bacillus subtilis & 1 & 0 & 0 & 0 \\
Citrobacter freundii & 2 & 0 & 0 & 0 \\
Enterobacter aerogenes & 1 & 0 & 0 & 0 \\
Enterobacter cloacae & 1 & 0 & 0 & 0 \\
Escherichia coli & 2 & 0 & 0 & 0 \\
Klebisiella pneumonia & 2 & 0 & 0 & 0 \\
Morganella morganii & 2 & 0 & 0 & 0 \\
Proteus mirabilis & 3 & 0 & 0 & 0 \\
Shigella sonnei & 2 & 0 & 0 & 0 \\
Staphylococcus aureus & 1 & 0 & 0 & 0 \\
Staphylococcus saprophyticus & & 0 & 0 & \\
\hline & & 0 & 0 & 0
\end{tabular}


(Invitrogen) and photographed with UV illumination by a photodocumentation system (Loccus, L-PIX HE).

\section{Primer design}

For multiplex PCR analysis, two primers pairs were used: Inv-A, which is specific for Salmonella spp. described by Fratamico and Strobaugh (1998) and IE 1, specific for $S$. Enteritidis described by designed by Wang and Yeh (2002), amplifying fragments of $796 \mathrm{bp}$ and $316 \mathrm{bp}$. A third primer pair specific for Salmonella Typhimurium was designed in this work to amplify a fragment between 796 and $316 \mathrm{bp}$ (Table 2). Primers were selected from a gene sequence involved in flagellin synthesis from complete sequence from Salmonella Typhimurium strain AY649720, recovered from the GenBank database. Primers were designed using the software Primer 3.0 (Rozen et al., 2000). The specificity of pair of primers was evaluated by nucleotide similarity searched with the BLAST algorithm at the NCBI website (http://www.ncbi.nlm.nih.gov). Additionally, the PCR amplification was evaluated with DNA samples from the bacterial species listed in Table 2.

\section{PCR sensitivity}

PCR sensitivity was determined using suspensions of S. Enteritidis and S. Typhimurium in BHI broth incubated at $37{ }^{\circ} \mathrm{C}$ overnight without and with introduction of chicken swab. A serial of 10 -fold dilutions was prepared in phosphate-buffered peptone water to obtain suspensions containing $10^{3}-10^{8} \mathrm{CFU}$ of each Salmonella serovar per $\mathrm{ml}$. The cell bacterial concentrations were estimated by plating $0.1 \mathrm{~mL}$ of each dilution onto BHI agar. The plates were incubated at $37^{\circ} \mathrm{C}$ overnight, and colonies were counted. Experiments were conducted in triplicate. One milliliter of each dilution was centrifuged at $12,000 \mathrm{x}$ g for $10 \mathrm{~min}$ and the pellets washed twice with $900 \mu \mathrm{L}$ of $0.85 \%$ saline solution. The pellets were resuspended in $500 \mu \mathrm{L}$ of $1 \%$ Triton $\mathrm{X}-100$, heated in a water bath for $10 \mathrm{~min}$, cooled in ice, and centrifuged at $8000 \mathrm{xg}$ for $5 \mathrm{~min}$. The supernatants containing DNA of each dilution were used in m-PCR, adding five microliters of each serovar Enteritidis and Typhimurium DNA separately and both mixed in order to test the triplex specificity and sensitivity.

\section{Sampling}

Newly hatched Cobb chicks were obtained from a commercial broiler hatchery. Feed and drinking water were provided ad libitum. Thirty swabs from cloacae were assessed for the presence of Salmonella spp Enteritidis and Typhimurium on the dietary treatment at 10 and 20 days of chicken age and during the first day of the chick's housing period.

\section{Results and Discussion}

\section{Specificity and sensitivity of multiplex PCR}

In the present study, two primer sets were selected to detect Salmonella spp and the serovar Enteritidis and a pair of primers was designed to detect Typhimurium serovar simultaneously using a m-PCR. The pair of primers used to detect Salmonella at genus level codifies the invasion protein A gene (InvA), widely distributed in Salmonella spp (Rahn et al., 1992; Fratamico 2003; Germini et al., 2009). The pair of Enteritidis-specific primers, using the IE-1 DNA sequence is an Insertion Element, found only in this serovar (Wang and Yeah, 2002; Silva et al., 2011). The pair of primers used to detect $S$. Typhimurium was designed in this work using the gene sequence involved in flagellin synthesis, ie, the Flic-C gene (Soumet et al., 1999) gives an amplicon size of $432 \mathrm{bp}$ located in the central region of the gene (from nucleotides 794 to 1226) based on DNA sequence from AY649720.1. To asses and evaluate the specificity of the three primers sets, the m-PCR was first optimized and then tested with DNA templates prepared from the 38 bacterial strains, including positive control strains, as shown in Table 1. All bacteria from Salmonella genera showed a 796 bp amplicon, yielded from Inv-A pair of primer amplification. $S$. Enteritidis showed two amplicons, a $796 \mathrm{bp}$ and a $316 \mathrm{bp}$ amplicon, specific to this serovar, yielded from IE-1 amplification. $S$. Typhimurium also showed a 796 bp amplicon and a 432 bp specific amplicon, resulted from Flic-C pair of primers amplification. These results confirmed that the Inv-A, IE1 and Flic-C genes were appropriate candidates for the specific detection of Salmonella spp. and serovars Enteritidis and Typhimurium. In recent years, many studies have been published using specific primers complementary to virulence genes in combination

Table 2 - Primers used for identification of Salmonella spp. Salmonella Enteritidis and Typhimurium.

\begin{tabular}{lclcc}
\hline Primers & Length & Primer sequence $5, \rightarrow 3$, & Amplification product (bp) & Source \\
\hline Inv-A forward & 22 & CGG TGG TTT TAA GCG TAC TCT T & 796 & Fratamico (2003) \\
Inv-A reverse & 21 & CGA ATA TGC TCC ACA AGG TTA & Wang and Yeh (2002) \\
IE-1 forward & 20 & AGT GCC ATA CTT TTA ATG AC & 316 & This work \\
IE-1 reverse & 19 & ACT ATG TCG ATA CGG TGG G & 432 & \\
Flic-C forward & 20 & CCCGCTTACAGGTGGACTAC & & \\
Flic-C reverse & 20 & AGCGGGTTTTCGGTGGTTGT & & \\
\hline
\end{tabular}


with different pre-enrichment strategies (Cardona-Castroa et al., 2009, Kumar at al., 2009, Lim et al., 2003). Soumet et al. (1999) developed an m-PCR assay, but they were not able to detect Salmonella without the isolation of suspicious colonies. In this study we were able to detect Salmonella using pre enrichment culture and it was not necessary to submit the samples to the enrichment step and isolation of suspicious colonies thus reducing the time of analysis in at least 1.5 days. Another advantage is the simplicity of DNA extraction (by boiling), even though the most part of pathogens detection using feces, the DNA is extracted after a treatment with proteinase $\mathrm{K}$ and phenolchloroform to eliminate the PCR inhibitors (Frankel et al., 1990, Stone et al., 1999). These techniques, however, greatly increase the detection cost and time and certain chemicals as phenolchloroform also are able to inhibit PCR.

The m-PCR efficiency was not affected in the detection of target microorganisms when DNA of Salmonella Enterititdis and Typhimurium were mixed as observed by comparing PCR product intensity on agarose gel after staining. The m-PCR detection sensitivity was approximately $10^{2} \mathrm{CFU} / \mathrm{mL}$ of $S$. Enteritidis $\mathrm{mL}^{-1}$ and $S$. Typhimurium in phosphate-buffered peptone water (Figure 1). While these serovars were cultured with swab material this sensitivity was reduced to $10^{3} \mathrm{CFU} / \mathrm{mL}$, showing matrix effect in amplification results. This was possible because swab as fecal samples might contain PCR inhibitors.

\section{Analysis of cloacal chicken swabs}

Ninety chicken cloacae swabs from poultry collected on the first, tenth, and twentieth days of age were cultured in peptone water for $18 \mathrm{~h}$ and used to extract DNA for $\mathrm{m}-\mathrm{PCR}$ assays. It was verified whether the m-PCR assay could be applied in samples from field conditions (Figu-

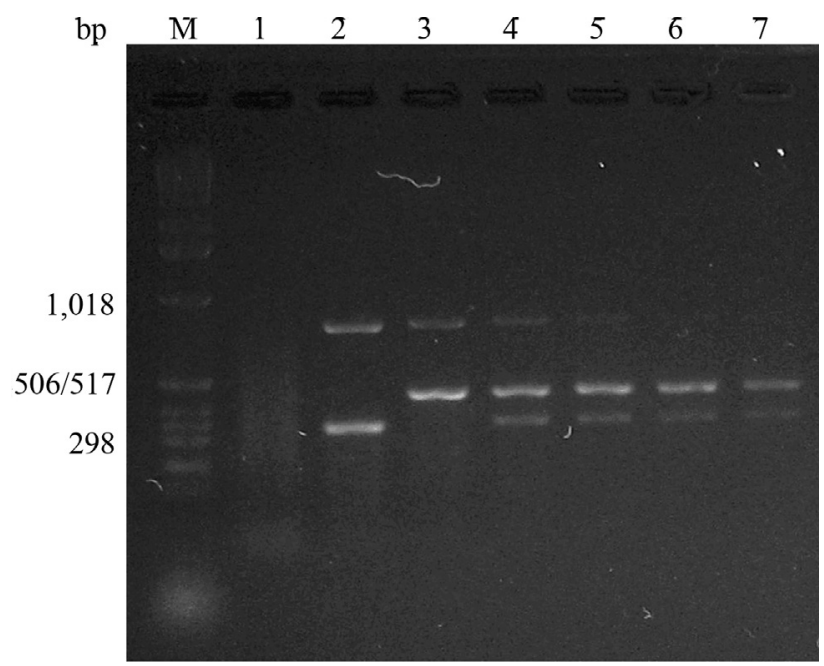

Figure 1 - Multiplex PCR assay with the primers sets Inv-A, IE-1 and Flic-C, respectively. Lane M: $1 \mathrm{~Kb}$ ladder (Invitrogen); Lane 1: Negative control; Lane 2: $S$. Enteritidis (ATCC 14028); Lane 3: $S$. Typhimurium; Lanes 4 to 7: PCR results from a serial of 10-fold dilutions prepared in phosphate-buffered peptone water containing $10^{5}$ to $10^{2} \mathrm{CFU} / \mathrm{mL}$ of $S$. Enteritidis and $S$. Typhimurium. re 2). The amplification of Salmonella spp and serovars Enteritis and Typhimurium in chicken swab samples naturally infected presented a reliable sensitivity of the method.

Salmonella spp., S. Enteritidis and Typhimurium were not detected in any of the first day collected chicken samples suggesting that the birds were originally Salmonella-free at the hatchery. However, on the tenth day, 12 samples were positive for Salmonella spp., five of them belonging to the serovar Enteritidis and 2 of them to the Typhimurium serovar (Table 3 ). Finally, on the twentieth day, ten samples were positive for Salmonella spp., and six of them belonging to the serovar Enteritidis and none Typhimurium serovar was detected. This tendency in reduction of contamination throughout 20 days was possible because the newly hatched chicks are highly susceptible to infection with Salmonella than the older because the acquisition of microorganisms that constitute the normal chickens intestinal microbiota as pointed is gradual (Sterzo et al., 1994). Infected young birds excrete Salmonella in the feces at greater rates (higher concentration of bacteria and higher number of birds) when compared to excretion by older infected chickens (Smith et al., 1995). Therefore it is possible to conclude that the m-PCR assay described herein was found to be a rapid and simple

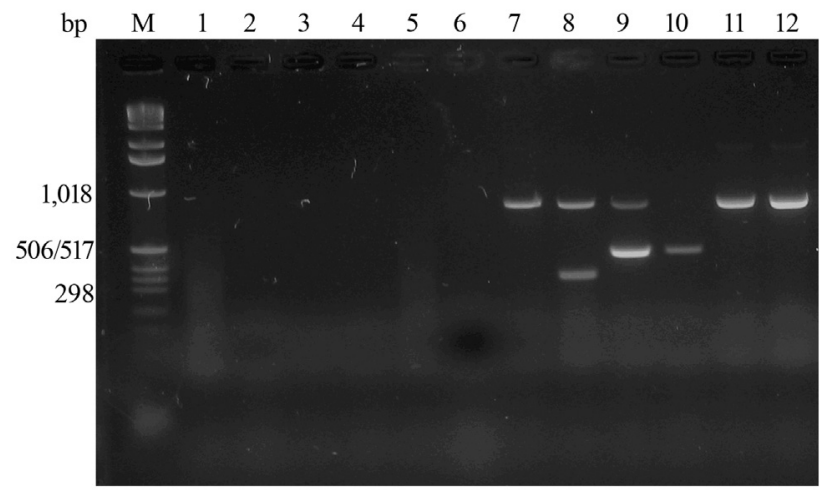

Figure 2 - Fragments resulting from m-PCR of chicken cloacal swabs. Lane M: $1 \mathrm{~kb}$ ladder (Invitrogen); Lane 1: negative control. Lanes 2 to 6: non contaminated chicken swabs samples. Lanes 7, 8 and 9: PCR positive controls: $S$. Infantis, $S$. Enteritidis and $S$. Typhimurium, respectively. Lanes 10 to 12: positive naturally contaminated swabs samples.

Table 3 - Number of samples positive for Salmonella spp., S. Enteritidis and Typhimurium from swabs cloacae of poultry.

\begin{tabular}{lcccc}
\hline & \multicolumn{4}{c}{$\begin{array}{c}\text { Number of contaminated chicken samples per } \\
\text { day of life }\end{array}$} \\
\cline { 2 - 5 } & first day & 10 days & 20 days & Total \\
\hline S. Enteritidis & $0 / 30$ & $5 / 30$ & $6 / 30$ & $11 / 90$ \\
S. Typhimuruim & $0 / 30$ & $2 / 30$ & $0 / 30$ & $3 / 90$ \\
Other (s) Salmonella * & $0 / 30$ & $5 / 30$ & $4 / 30$ & $9 / 90$ \\
Salmonella spp & $0 / 30$ & $12 / 30$ & $10 / 30$ & $22 / 90$ \\
\hline
\end{tabular}

*Represents Salmonella spp serovars of Salmonella enterica except the serovars Enteritidis and Typhimurium. 
method to detect the Salmonella genus and for the identification of $S$. Enteritidis and Typhimurium in chicken swab samples.

\section{Acknowledgments}

This research was supported by CNPq/MAPA (Process \#578315/2008-4) and Araucária Foundation/CNPq Pronex (Protocol \#09.277). FGP holds a postdoctoral CNPq scholarship (Process 151809/2008-9) and MS is a CNPq Research Fellow. We thank Dr Tereza Cristina Rocha Moreira de Oliveira from Londrina State University for the kind supply of the bacterial strains used in this work.

\section{References}

Aabo S, Rasmussen OF, Rossen L, Sørensen PD, Olsen JE (1993) Salmonella identification by the polymerase chain reaction. Mol Cell Probes 7:171-178.

Araj GF, Chugh TD (1987) Detection of Salmonella spp. in clinical specimens by capture enzyme-linked immunosorbent assay. J Clin Microbiol 25:2150-2153.

Aspinall ST, Hindle MA, Hutchinson DN (1992) Improved isolation of salmonellae from feces using a semisolid Rappaport-Vassiliadis medium. Eur J Clin Microbiol Infect Dis 11:936-939.

Cardona-Castroa N, Sánchez-Jimeneza M, Lavaletta L, Munhoz N, Morenoc J (2009) Development and evaluation of a multiplex polymerase chain reaction assay to identify Salmonella serogroups and serotypes. Diag Microb Infec Dis 65:327-330.

Doyle MP, Erickson MC (2006) Reducing the carriage of foodborne pathogens in livestock and poultry. Poultry Sci 85:960-973.

Frankel G, Riley L, Giron A, Valmassoi J, Friedmann AN, Strockbine NA, Falkow S, Schoolnik GK (1990) Detection of Shigella in feces using DNA amplification. J Infect Dis 16:52-1256.

Fratamico PM (2003) Comparison of culture, polymerase chain reaction (PCR), TaqMan Salmonella, and Transia Card Salmonella assays for detection of Salmonella spp. in naturally-contaminated ground chicken, ground turkey, and ground beef. Mol Cell Probes 17:215-221.

Fratamico PM, Strobaugh TP (1998) Simultaneous detection of Salmonella spp. and Escherichia coli O157:H7 by multiplex PCR. J Food Ind Microbiol Biotech 21:92-98.

Germini A, Masola A, Carnevali P, Marchelli R (2009) Simultaneous detection of Escherichia coli O175:H7, Salmonella spp., and Listeria monocytogenes by multiplex PCR. Food Cont 20:733-738.

Hald T, Vose D, Wegener HC, Koupeev T (2004) A Bayesian approach to quantify the contribution of animal-food sources to human salmonellosis. Risk Anal 24:255-269.

Kottwitz LBM, Oliveira TCRM, Alcocer I, Farah SMSS, Abrahão WSM, Rodrigues DP (2010) Avaliação epidemiologica de surtos de salmonelose ocorridos no período de 1999 a 2008 no estado do Paraná, Brasil. Acta Scientia 32:9-15.

Kumar R, Surendran PK, Thampuran N (2009) Detection and characterization of virulence factors in lactose positive and lactose negative Salmonella serovars isolated from seafood. Food Cont 20:376-380.

Malorny B, Huehn S, Dieckmann R, Kramer N, Helmuth R (2009) Polymerase chain reaction for the rapid detection and serovar identification of Salmonella in food and feeding stuff. Food Anal Meth 2:81-95.

Lim YH, Hirose K, Izumiya H, Arakawa E, Takahashi H, Terajima J, Itoh KI, Tamura K, Kim SI, Watanabe H (2003) Multiplex polymerase chain reaction assay for selective detection of Salmonella enterica serovar Typhimurium. Jpn J Infect Dis 56:151-155.

Popoff MY, Bockemuhl J, Gheesling LL (2003) Supplement 2001 (no. 45) to the Kauffmann-White scheme. Res Microbiol 154:173-174.

Rahn K, De Grandis SA, Clarke RC, Curtiss R, Gyles CL (1992) Amplification of an invA gene sequence of Salmonella Typhimurium by polymerase chain reaction as a specific method of detection of Salmonella. Mol Cell Probes 6:271279.

Rasschaert G, Houf K, Godard C, Wildemauwe C, PastuszczakFrak M, De Zutter L (2008) Contamination of carcasses with Salmonella during poultry slaughter. J Food Prot 71:146152.

Rozen S, Skaletsky JH (2000) Primer3 on the WWW for general users and for biologist programmers. In: Krawetz S, Misener S (eds) Bioinformatics Methods and Protocols: Methods in Molecular Biology. Humana Press, Totowa, pp 365-386.

Silva DSP, Canato T, Magnani M, Alves J, Hirooka EY, Oliveira TCRM (2011) Multiplex PCR for the simultaneous detection of Salmonella spp. and Salmonella Enteritidis in food. Int J Food Sci Tech 46:1502-1507.

Smith HW (1965) The development of the flora of the alimentary tract in young animals. J Pathol Bacteriol 90:495-513.

Soumet C, Ermel G, Rose V, Rose N, Drouin P, Salvat G, Collin P (1999) Identification by a multiplex PCR-based assay of Salmonella Typhimurium and Salmonella Enteritidis strains from environmental swabs poultry houses. Lett App Microbiol 29:1-6.

Sterzo EV, Paiva JB, Penha-Filho RAC, Berchieri-Junior A (2005) Time required to protect the intestinal tract of chicks against Salmonella enterica serovar Enteritidis using competitive exclusion. Braz J Poultry Sci 7:119-122.

Stone GG, Oberst OD, Hays MP, McVey S, Chengappa MM (1994) Detection of Salmonella serovars from clinical samples by enrichment broth cultivation-PCR procedure. J Clin Microbiol 32:1742-1749.

Wang SJ, Yeh DB (2002) Designing of polymerase chain reaction primers for the detection of Salmonella Enteritidis in foods and faecal samples. Lett App Microbiol 32:422-427.

All the content of the journal, except where otherwise noted, is licensed under a Creative Commons License CC BY-NC. 